\title{
A competitive immunosorbent assay for detection of Pseudomonas pseudomallei exotoxin
}

\author{
G. ISMAIL*, M. NOOR EMBI*, O. OMAR, J. C. ALLEN and C. J. SMITH†
}

Research Division, North East Wales Institute, Deeside, C/wyd CH5 4BR and *The National University of Malaysia, Sabah Campus, Kota Kinabalu, Malaysia

\begin{abstract}
Summary. The development of monoclonal antibody and enzyme-linked immunosorbent assay (ELISA) techniques has made possible the detection of specific antigens at extremely low concentrations. Diagnosis of recalcitrant diseases such as melioidosis depends upon either early isolation and identification of the causative organism or the identification of a specific marker antigen, Pseudomonas pseudomallei exotoxin, in serum; the latter is better because it allows more rapid and simple diagnosis. A method of detecting exotoxin concentrations of $>16 \mathrm{ng} / \mathrm{ml}$ by an ELISA based on a monoclonal antitoxin is here described; it is significantly more sensitive than the mouse lethality test (lower threshold $30 \mu \mathrm{g} / \mathrm{ml}$ ) currently in use and an in-vitro cytotoxicity test (lower threshold $10 \mu \mathrm{g} / \mathrm{ml}$ ) that we have developed and describe here.
\end{abstract}

\section{Introduction}

Pseudomonas pseudomallei causes melioidosis, a fulminating and usually fatal disease of man and animals in South East Asia and tropical Australia. The ability of $P$. pseudomallei to produce lethal toxic filtrates has been demonstrated by several investigators (Liu, 1957; Colling et al., 1958; Heckly and Nigg, 1958; Heckly, 1964). The extent to which the toxic product of $P$. pseudomallei is involved in human and animal infections remains unclear. The uncertainty concerning the role of exotoxin in the pathogenesis of melioidosis stems in part from the lack of a simple, precise, highly sensitive test for $P$. pseudomallei exotoxin.

At present, the only assay systems for detecting $P$. pseudomallei exotoxin are bioassays, the most common of which is the mouse lethality test (Liu, 1957). This method is cumbersome, requires large numbers of mice, is at best only semi-quantitative, and so is impracticable for many routine laboratories. Recently, we have partially purified the $P$. pseudomallei exotoxin and used this relatively pure material to develop a serological test for the exotoxin by competitive inhibition of an enzyme-linked immunosorbent assay (ELISA). We have also used this sensitive and specific assay to study the effect of culture conditions and medium on the production of exotoxin by the organism.

Received 11 Jun. 1986; accepted 1 Oct. 1986.

$\uparrow$ Correspondence should be sent to Dr C. J. Smith.

\section{Materials and methods}

\section{Bacteria}

$P$. pseudomalle $i$ was obtained from the Microbiology Department, Faculty of Medicine, National University of Malaysia, Kuala Lumpur. The strain was isolated from a male patient who died of melioidosis. The organisms were propagated on Brain Heart Infusion Agar (BHIA) slants and stored at $4^{\circ} \mathrm{C}$.

\section{Determination of bacterial growth}

The bacterial cell mass was pelleted by centrifugation of the culture and was resuspended in an equal volume of phosphate-buffered saline, $p \mathrm{H} \mathrm{7.4} \mathrm{(PBS).} \mathrm{A} \mathrm{sample} \mathrm{of} \mathrm{the}$ resulting suspension was diluted further in $\mathrm{PBS}$ to $\mathrm{OD}_{575}$ values in the range $0 \cdot 1-0 \cdot 8$. An $\mathrm{OD}_{575}$ of $0 \cdot 3$ represented

Table. Exotoxin production by $P$. pseudomallei in BHIB in various conditions

\begin{tabular}{l|ccc}
\hline $\begin{array}{c}\text { Conditions of } \\
\text { culture and } \\
\text { medium }\end{array}$ & $\begin{array}{c}\text { Incuba- } \\
\text { tion } \\
\text { tempera- } \\
\text { ture }\end{array}$ & $\begin{array}{c}\text { Growth-mean } \\
\text { dry weight of } \\
\text { cells, mg (SEM) }\end{array}$ & $\begin{array}{c}\text { Exotoxin } \\
\text { production-ml (SEM) }\end{array}$ \\
\hline $\begin{array}{l}\text { BHIB } \\
\text { BHIB + } \\
\text { glycerol 2\% }\end{array}$ & RT & $0.76(0.05)$ & $86(9)$ \\
$\begin{array}{l}\text { BHIB } \\
\text { BHIB + } \\
\text { glycerol 2\% }\end{array}$ & RT & $0.81(0.07)$ & $157(13)$ \\
\hline
\end{tabular}

BHIB $=$ Brain Heart Infusion Broth $; \mathrm{RT}=$ Room Temperature 
a concentration of organisms equal to $0.35 \mathrm{mg}$ (dry weight $) / \mathrm{ml}$.

\section{Isolation of P. pseudomallei exotoxin}

$P$. pseudomallei was grown in Brain Heart Infusion Broth (BHIB) containing mucin $1 \%$ and glycerol $2 \%$ at $37^{\circ} \mathrm{C}$ in static conditions for 7 days. The culture was harvested by centrifugation at $32000 \mathrm{~g}$ for $40 \mathrm{~min}$ (Sorvall RL-53 Superspeed; 14000 rpm, Rotor GSA). The resultant supernate was centrifuged at $55000 \mathrm{~g}$ for $40 \mathrm{~min}$ (Beckman L 3-50 Ultracentrifuge; $30000 \mathrm{rpm}$, Rotor $50.2 \mathrm{Ti})$. The supernate was then membrane-filtered $(0.45 \mu \mathrm{m}$; Millipore) to remove any remaining cells. The cell-free filtrate was dialysed twice against PBS for $24 \mathrm{~h}$. The resulting crude toxin extract was concentrated to a volume of $20-30 \mathrm{ml}$ through an ultra-filtration unit (Cole Palmer), at a cut-off point of $10000 \mathrm{~mol}$. wt, with a nitrogen pressure of not more than 20 p.s.i. At the end of the concentration step, the sample was lyophilised and the powder stored at $-20^{\circ} \mathrm{C}$. In the final step of exotoxin isolation, the lyophilised sample was resuspended in PBS and applied to a G100 Sephadex column. The single peak that showed toxic activity in the mouse lethality test was collected and stored at $-20^{\circ} \mathrm{C}$. SDS-polyacrylamide gel electrophoretic (SDS-PAGE) analysis showed only one major band at mol. wt c. 31000 (Ismail et al., in press).

\section{Test of toxicity}

Toxicity of the exotoxin preparation was determined at each stage of the purification by intraperitoneal injection of $0.5 \mathrm{ml}$ of serially diluted test samples into groups of mice. Mortality was recorded for 7 days and the LD50 was calculated by the method of Reed and Muench (1938).

\section{Antiserum production}

Mice were immunised with a solution of exotoxin preparation $1.0 \mathrm{mg} / \mathrm{ml}$ mixed with an equal volume of Freund's complete adjuvant. The immunisation schedule used was that described by Galfré and Milstein (1981). Mice were test-bled routinely and those producing high titres were selected for hybridoma production. Sera from exsanguinated mice were collected and used as positive controls in subsequent assays.

Hybridoma production was by a modification of the polyethylene glycol technique of Kohler and Milstein (1975). The modifications were based on those outlined by Fazekas de St Groth and Scheidegger (1980). Antibody-producing hybrids were selected by cloning in soft agar and the clones expanded in vitro. Spent culture medium containing antibody activity was used in all assays.

\section{ELISA method}

The ELISA was performed by a modification of the method of Voller et al. (1976). Polystyrene flat-bottomed 96-well microtitration plates were used for the assay (NUNC Immunoplate II, Gibco Laboratories, Grand Island, NY, USA). Wells were coated with $100 \mu \mathrm{l}$ of purified exotoxin $(0.5 \mu \mathrm{g} / \mathrm{ml})$ in carbonate-bicarbonate binding buffer, $0 \cdot 1 \mathrm{M}, p \mathrm{H} 9 \cdot 6$. After overnight incubation at $4^{\circ} \mathrm{C}$, the plates were washed five times with PBS containing Tween $800.05 \%$ (PBST) and stored at $4{ }^{\circ} \mathrm{C}$. A $100-\mu 1$ sample of antiserum diluted in PBS was added to each appropriate well and the plates were incubated, with shaking, at room temperature for $30 \mathrm{~min}$. After incubation, the plates were washed five times with PBST and $100 \mu \mathrm{l}$ of peroxidase-labelled rabbit anti-mouse immunoglobulin G (Sigma Chemical Co., St Louis, MO, USA) diluted 1 in 200 in PBST was added. The plates were incubated for $20 \mathrm{~min}$ with shaking at room temperature, washed five times with PBST after which $100 \mu \mathrm{l}$ of substrate solution was added. The substrate solution was $\mathrm{H}_{2} \mathrm{O}_{2} \quad 0.012 \%$ in citrate buffer $(p \mathrm{H} 5.0)$ containing 2-2'-azinobis (3-ethylbenz-thiazoline sulphonic acid (ABTS) $6 \mathrm{mg} / \mathrm{ml}$. Reaction mixtures were incubated with shaking at room temperature for $10 \mathrm{~min}$. Control wells were treated identically, except that PBS replaced the serum. The OD was read at $405 \mathrm{~nm}$ in a Microelisa Reader (Dynatech).

\section{Competitive ELISA Test}

A competitive ELISA test was performed by the method of Yolken et al. (1977). A dilution of the test serum in PBS was selected that gave an absorbance value of 1.00 to 1.200 in wells coated with exotoxin. The serum was preincubated with increasing concentrations of exotoxin or lipopolysaccharide for $30 \mathrm{~min}$ at $37^{\circ} \mathrm{C}$, and then tested in the ELISA system. The reduction in absorbance by the addition of exotoxin was expressed as a percentage of the OD reading for a negative control. To determine exotoxin production in a culture of P.pseudomallei, $100 \mu \mathrm{l}$ of cell-free supernate of a $48-\mathrm{h}$ broth culture was preincubated with the test serum and then used in the ELISA. Control wells contained test serum preincubated with broth culture that had been inoculated with non-viable formalin-treated $P$. pseudomallei.

\section{Cytotoxicity Assay}

Cell-culture techniques were similar to those previously described (Allen et al., 1979). EB2 cells were seeded in 96-well flat-bottomed tissue culture plates and allowed to grow for $24 \mathrm{~h}$ at $37^{\circ} \mathrm{C}$ in an atmosphere of air $+\mathrm{CO}_{2} 5 \%$. All tissue-culture media contained fetal calf serum, Lglutamine and antibiotics (Gibco Lab., Grand Island, NY, USA). After $24 \mathrm{~h}$, increasing concentrations of exotoxin were added and the plates were incubated overnight. Radionucleotides and labelled amino acid (Radiochemical Centre, Amersham) were added to 
appropriate wells. After incubation for $4 \mathrm{~h}$, the cultures were harvested by a Titertek cell harvester and radioactivity determined by liquid scintillation counting. All cultures were tested in quadruplicate. To determine the effect of exotoxin on thymidine uptake by cells during the early period of incubation, cultures were harvested at hourly intervals after the addition of exotoxin.

\section{Results}

\section{Lethal toxicity in mice}

Preliminary studies were performed to determine the LD50 for mice of the purified exotoxin preparations. The LD50 of different batches was fairly uniform; the mean value was $29 \cdot 5 \pm 8 \cdot 0 \mu \mathrm{g}$ of protein.

\section{Titration of hybridoma supernate (CB4)}

Titration studies with hybridoma supernate showed a linear relationship between supernate dilution and net OD (fig. 1). The supernate from the hybridoma culture (CB4) gave a high titre with $P$. pseudomallei exotoxin in a direct ELISA for antibody to toxin. Indeed, a significant positive ELISA reaction was observed even at dilutions of $1.6 \times 10^{4}$, when the minimal usable absorbance value was fixed at a reading equivalent to twice that

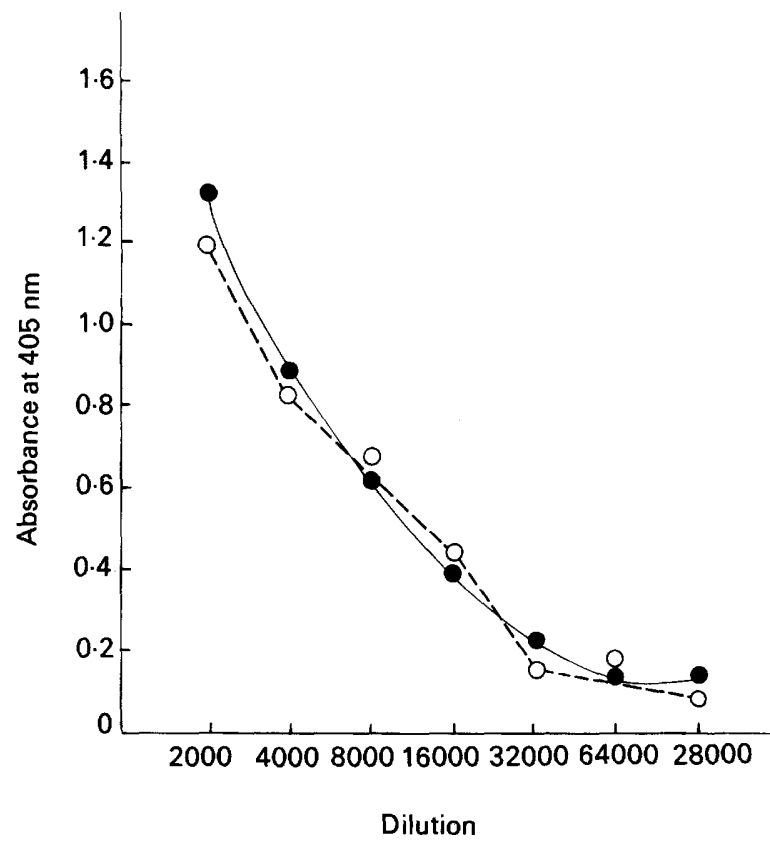

Fig. 1. ELISA reactivity $\left(\mathrm{OD}_{405}\right)$ at serial twofold dilutions of clone CB4 anti-exotoxin hybridoma supernate (-O-) and adsorbed supernate $(-\mathrm{O}-)$. obtained from negative control assays. The reactivity of antibody-containing supernates was unaffected by pre-absorption with bacterial growth medium (BHIB, mucin $1 \%$ and glycerol $2 \%$ ).

The titration results showed that the optimum antibody dilution for use in an inhibition assay for exotoxin would be 1 in 2000 . This dilution was then used in all our studies and a positive control at this dilution was included in every test plate, giving a standard reference value for all the results.

\section{Competitive ELISA for P. pseudomallei toxin}

Fig. 2 shows the results of a typical competitive ELISA in which $P$. pseudomalle $i$ exotoxin was used as the competitor antigen. The binding of the positive control supernate was inhibited $94 \%$ by purified exotoxin at a concentration of $50 \mu \mathrm{g} / \mathrm{ml}$. Similar concentrations of lipopolysaccharides of Salmonella sp. and E. coli produced inhibitions of $5-17 \%$. Pre-incubation of the positive control supernate with bacterial growth medium also failed to cause a decrease in ELISA reactivity in this system.

\section{Exotoxin levels in culture supernates}

The table shows exotoxin production by $P$. pseudomallei grown under different conditions. The competitive ELISA technique was used to determine the concentration of exotoxin in culture supernates. The amount of exotoxin was calculated from a standard curve generated for each microtitration plate by plotting the absorbance against

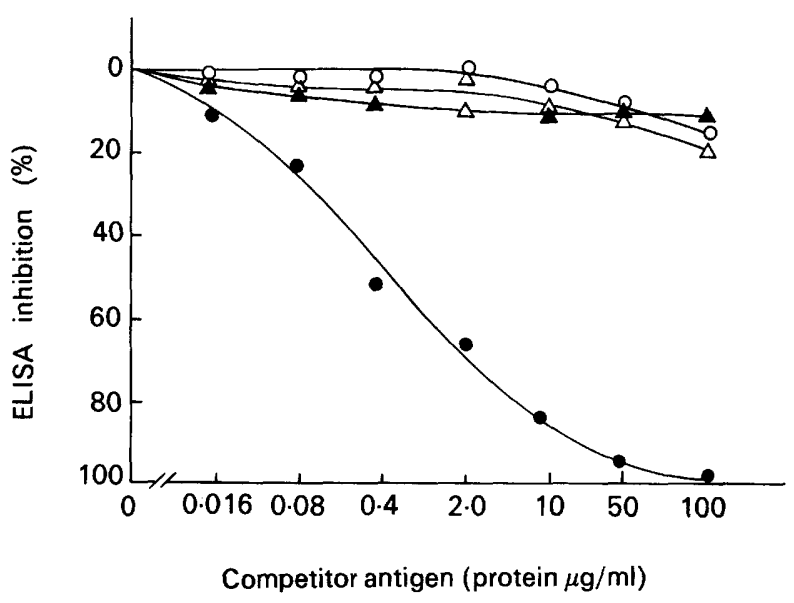

Fig. 2. Quantitative inhibition of ELISA reactivity by purified exotoxin (-○一), Salmonella sp. lipopolysaccharide $(-\triangle-)$, E. coli lipopolysaccharide (- - -) and BHIB + glycerol + mucin $(-\mathrm{O}-)$. The reference hybridoma supernate was used at a dilution of 1 in 2000 . 
concentrations of purified exotoxin added to wells $(50 \mathrm{ng}-1.0 \mu \mathrm{g} /$ well). Exotoxin production by $P$. pseudomallei was enhanced in the presence of glycerol $2 \%$. The addition of glycerol significantly increased the production of exotoxin in static cultures at room temperature and at $37^{\circ} \mathrm{C}$. This enhancement of exotoxin production was not due to a difference between growth rates because the addition of glycerol to the growth medium did not significantly increase the dry-weight yield of the cultures. However, significantly different growth rates and exotoxin production were observed in cultures grown at room temperatures and at $37^{\circ} \mathrm{C}$. Growth and exotoxin production were increased in cultures at $37^{\circ} \mathrm{C}$.

\section{Correlation between competitive ELISA and tissue- culture cytotoxicity assay}

The titration curves for the exotoxin obtained by ELISA and by cytotoxicity tests are shown in fig. 3 . Different concentrations of purified exotoxin were tested and there was close correlation of ELISA reactivity with cytotoxicity as determined by the effects on EB2 cells in culture. In the competitive ELISA test, inhibition of reactivity was observed at exotoxin concentrations as low as $16 \mathrm{ng} / \mathrm{ml}$. However, cytotoxicity, as measured by radiolabelled thymidine incorporation was not observed until the concentration of exotoxin was $c .2 \cdot 0 \mu \mathrm{g} /$ $\mathrm{ml}$. Above this threshold concentration, increases in exotoxin concentration to $10 \mu \mathrm{g} / \mathrm{ml}$ and $50 \mu \mathrm{g} / \mathrm{ml}$

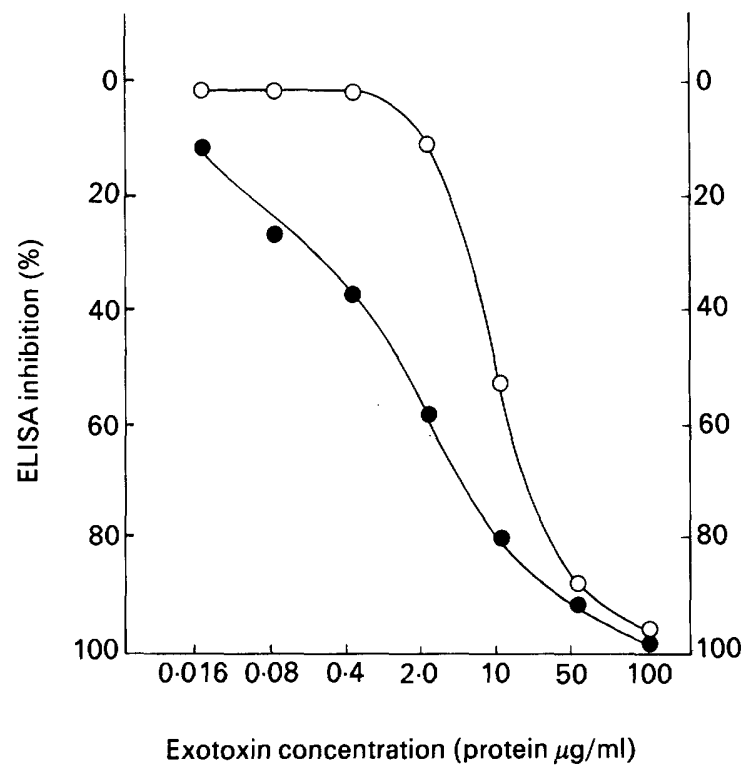

Fig. 3. Relationship between ELISA reactivity (-O-) and cytoxic activity ( $-\mathrm{O}-$ ) for exotoxin. resulted in $50 \%$ and $90 \%$ inhibition of ${ }^{3} \mathrm{H}$-thymidine uptake respectively.

\section{Discussion}

Our results show that $P$. pseudomallei exotoxin can be measured by a competitive ELISA technique. The specificity of the assay for anti-exotoxin antibodies is confirmed here and elsewhere (Ismail et al., in press) and is supported by the fact that the exotoxin preparation used for coating the microtitration plates showed a single major protein band on SDS-PAGE. The competitive ELISA reported here showed that anti-exotoxin activity could not be inhibited by purified lipopolysaccharides of $E$. coli or Salmonella sp., confirming that the exotoxin preparation was not significantly contaminated with bacterial endotoxins. Growth medium initially seeded with non-viable $P$. pseudomallei also failed to show any effect on the ELISA reactivity, further confirming that our antibody preparations were specific for the active exotoxin and that the antibody did not cross-react with other antigens present in cell pellets or culture broth.

Our studies also show that the assay could be used to detect exotoxin in culture supernates. Exotoxin production in cultures was enhanced in the presence of glycerol. The increase in exotoxin concentration was clearly not due to an increase in bacterial growth. This lack of correlation between bacterial growth and toxin production implies that the lethal activity observed in all toxin-positive culture supernates was not due to endotoxin because the yield of lipopolysaccharide should parallel bacterial growth. Whether the increased.exotoxin concentration observed in growth medium containing glycerol was due to the specific induction of exotoxin synthesis by the cells or to increased secretion of intracellular exotoxin into the surrounding medium is not clear at present. Enhancement of $P$. aeruginosa exotoxin A production in the presence of exogenously added glycerol has been reported previously (Liu, 1973). The availability of the competitive ELISA technique described here for quantification of $P$. pseudomallei exotoxin should provide a sensitive and specific tool for future studies of the factors influencing, and mechanisms of, exotoxin production by this organism.

We have also shown that the competitive ELISA procedure for exotoxin measurement compares favourably in sensitivity and specificity with that of an in-vitro cytotoxicity assay. Indeed the ELISA technique described was considerably more sensitive than the toxicity assay in detecting toxin levels 
of $>16 \mathrm{ng} / \mathrm{ml}$, compared with the lower detection limit of the cytotoxicity assay of $>10 \mu \mathrm{g} / \mathrm{ml}$.

The role of exotoxin in the pathogenesis of $P$. pseudomallei infection is not yet clear. If the toxin is responsible for the lethal effects of melioidosis, a survey of the distribution of toxigenic strains of $P$. pseudomallei in its natural environment could provide important information about the epidemiology, dissemination and mode of infection of melioidosis in endemic regions. Moreover, the ELISA technique described here could be routinely used to determine the occurrence of toxin-producing strains in clinical isolates and further clarify the role of exotoxin in the pathogenesis of melioidosis.

Most cases of melioidosis have been reported in developing countries such as Burma, Malaysia and Vietnam where facilities for a comprehensive

\section{REFERENCES}

Allen J C, Smith C J, Hussain J I, Thomas J M, Gaugas J M 1979 Inhibition of lymphocyte proliferation by polyamines requires ruminant-plasma polyamine oxidase. European Journal of Biochemistry 102: 153-158.

Colling M, Nigg C, Heckly R J 1958 Toxins of Pseudomonas pseudomallei. I. Production in vitro. Journal of Bacteriology 76: 422-426.

Fazekas de St Groth S, Scheidegger D 1980 Production of monoclonal antibodies: strategy and tactics. Journal of Immunological Methods 35: 1-21.

Galfrè G, Milstein C 1981 Preparation of monoclonal antibodies: strategies and procedures. In: Langone $\mathrm{L} J$, Van Vunakis H (eds) Methods in enzymology 73. Academic Press, New York. pp. 3-46.

Heckley R J 1964 Differentiation of exotoxin and other biologically active substances in Pseudomonas pseudomallei filtrates. Journal of Bacteriology 88: 1730-1736.

Heckley R J, Nigg C 1958 Toxins of Pseudomonas pseudomallei. II. Characterization. Journal of Bacteriology 76: 427-436.

Ismail G, Allen J C, Smith C J Enzyme-linked immunosorbent survey on the distribution of $P$. pseudomallei are limited. The ELISA method offers several advantages to such countries. The reduced cost and convenience of performing this assay in microtitration plates make it potentially useful as a research tool in screening for non-toxigenic strains or mutants of $P$. pseudomallei for future vaccine development. ELISA is sensitive and specific and uses stable and inexpensive reagents and simple equipment. Once appropriate conditions are set, the assay may be performed simply and reproducibly.

We gratefully acknowledge support for this work from the European Economic Community, under the Science and Technology for Development scheme, subprogramme Medicine, Health and Nutrition in the Tropics.

assay for antibody to Pseudomonas pseudomallei exotoxin (in press).

Kohler G, Milstein C 1975 Continuous cultures of fused cells secreting antibody of predefined specificity. Nature 256: 495-497.

Liu P V 1957 Survey of hemolysin production among species of pseudomonads. Journal of Bacteriology 74: 718-727.

Liu P V 1973 Exotoxins of Pseudomonas aeruginosa. I. Factors that influence the production of exotoxin A. Journal of Infectious Diseases 128: 506-513.

Reed L J, Muench H 1938 A simple method of estimating fifty percent end points. American Journal of Hygiene 27: 493497.

Voller A, Bidwell D, Bartlett A 1976 Microplate enzyme immunoassays for the immunodiagnosis of virus infections. In: Rose N Friedman H (eds) Manual of clinical immunology. American Society for Microbiology, Washington, pp. 506-512.

Yolken R H, Greenberg H B, Merson M H, Sack R B, Kapikian A Z 1977 Enzyme-linked immunosorbent assays for detection of Escherichia coli heat-labile enterotoxin. Journal of Clinical Microbiology 6 : 439-444. 